\title{
GADES AND THE MEDITERRANEAN: A PROCESS OF INTEGRATION
}

\author{
Bruno dos Santos Silva*
}

\begin{abstract}
The impetus for this paper is to present possible contributions of the Network Theory approach to the analysis of the Roman presence in Turdetania by the end of the $1^{\text {st }}$ millennium BC. Firstly, we discuss how some written sources, such as Strabo's Geography, describe this region and how the countryside and coastal areas are mentioned. Secondly, we present how contemporary historiography makes use of Network Theory to investigate numerous issues of Ancient History. Finally, we point out a proposal for Social Network Analysis (SNA) to questions regarding Turdetania before and after Roman occupation.
\end{abstract}

Keywords: Turdetania, Network Theory, Ancient History, Strabo, Gades.

\section{1.}

\section{Introduction}

As historians, we are always asking ourselves how to approach our research objects. And this is one of the motivations of this paper. Since the beginning of my research, I have focused on the study of the Iberian Peninsula in Antiquity. However, inasmuch as the research goes on, its scope has been reduced to the city of Gades in the late Republican era. Nevertheless, this hyper-spe-

* PhD student from the University of São Paulo, Brazil. History Department, Ancient History chair. bruno.santos.silva@usp.br. 
cialization has always bothered me, because I was never satisfied with the limited analysis I had to do. I could not explore only a few aspects of the sources. There were so many features and so many levels to look through that all investigations felt shallow, superficial and incomplete. Therefore, I have been trying to find new ways of approaching this subject in order to avoid a hyperspecialized work.

This article will present a tiny fraction of this problem. As far as the description of Gades is concened, it appears in book three of Strabo's Geography, an extent description of the known world at the Turn of the First Millennium. Strabo wrote as follows:

The two that have grown most in fame and in power are Corduba and the city of the Gaditanians: the latter, because of the maritime commerce and because it associated itself with the Romans as an ally (Strabo 3.2.1) ${ }^{1}$.

The ancients seem to have called the Baetis River "Tartessus"; and to have called Gades and the adjoining islands Erytheia (Strabo 3.2.11).

Here live the men who fit out the most and largest merchant-vessels, both for Our Sea and the outer sea, although, in the first place, it is no large island they live in, and, secondly, they do not occupy much of the continent opposite the island, and, thirdly, they are not well-off in the possession of other islands; indeed, they live mostly on the sea, though a mere few keep at home or else while away their time at Rome (Strabo 3.5.3).

These are only three of the numerous entries of Gades in Strabo's work. This author was a scholar from an aristocratic family of the city of Amasya, the capital of the Kingdom of Pontus, ruled by Mithridates. Strabo's Geography dates from the beginning of the first century $\mathrm{AD}$ and consisted of seventeen books, each one describing a part of the oikoumene. It is possible to state that Gades

1 All translations of Strabo's work were retrieved from The Geography of Strabo (1960). 
has a prominence in the Iberian Peninsula context due to the fact that one-fifth of the $3^{\text {rd }}$ book of Geography is dedicated to the description of this city. It is, by far, the best-described city of Iberia (Silva, 2013: 91-95).

Frequently, the passages quoted above are interpreted as a demonstration of the incorporation of Gades to a new order that Rome was imposing onto the people of Iberia, from the end of the Second Punic War. A good example of this kind of interpretation is found in the Spanish translation of the $3^{\text {rd }}$ book of Strabo's Geography made by García y Bellido, España y los españoles hace dos mil años según la Geografia de Estrabón (1945). On the one hand, the comments made by this scholar have a very strong nationalist component, from the book's title to his continuous translation choices that praise the ancient Spaniards. On the other hand, the author also states that the Romans have a very strong presence in the transformations that, one day, would lead to the birth of the Spanish nation. Indeed, the presence of the Romans is a very important component of Strabo's report, but we need to acknowledge that there is more at stake, for example, Gade's maritime experience, its proximity with the ancient Tartessians, or even the Greek mythological element that is very often present in the description. One cannot also forget the intense Phoenician background of the city's foundation story [3.5.5], as well as the ethnical compound of the shores of the region where Gades is located [3.2.13].

The question arises here again: how can we deal with such a complex source of information? In other words, how can we fully understand the work of an aristocrat from Asia Minor (Strabo 12.3.33), who speaks Greek, travels through the most important harbors of the East and Central Mediterranean (Strabo 2.5.11), and who also writes about a city from the extremities of the inhabited world? How can we interpret so many different assumptions about this city? Among these statements, we have: a Greek mythological memory; oral traditional narratives about the Phoenician foundation of Gades; its important relationship with the Tartessos; wealthy people better known for their work with the metal trade; and, assumptions derived from the contemporary reports about the productive activities of the city of the Gaditani- 
ans and its geopolitics. How can one combine all of these data, not to mention other available information not mentioned here?

We have tons of excellent philological analyses of Strabo's work, for example, Ettore Pais (1886), Germaine Aujac (1966), François Lasserre (1982), Katherine Clarke (1997) and Daniela Dueck (2000). In their particular ways, they all make great contributions to a better understanding of this valuable source. My goal is much simpler and, at the same time, a broader one: with the available sources, I want to study the nature of the interactions of the city of Gades with the hinterland of the Guadalquivir valley by the end of the first millennium BC.

A traditional narrative of the history of a city is always possible, and there are some interesting examples in literature. In the book Nueva historia de Cádiz: Antigüedad (2011), Francisco Javier Lomas Salmonte presents a narrative about the foundation of the city by the Phoenicians, Carthage's domination and the incorporation of the city into the Roman Empire. It is an excellent work, but it maintains a structure that is not only conventional, but also uncritical, as the sources are used as examples instead of being analyzed with a range of various methodological tools. Nevertheless, the official story of Cadiz is not the solution that I think we should have in mind. Instead, I would like to propose a new look at this subject. An approach closer to our "zeitgeist" - in other words, an approach that encompasses our desire to understand the world, which seems to be getting smaller, more connected, but also poorer, less equal and more violent. We have been seeing the development of research proposals that intend to articulate local stories with broader historical processes. Those researchers use what Carl Knappet (2013) calls "network thinking".

\section{2.}

\section{Network Theory and Ancient History}

We think in terms of networks. We can see things as nodes with connections between them, "like joining dots on the map" (Malkin, Constantakopoulou and Panagopoulou, 2007: 2). This kind 
of descriptive network can be found in many historical works. Fernand Braudel's masterpiece La Méditerranée et le Monde Méditerranéen a l'époque de Philippe is, perhaps, the best example for this statement. What new studies do nowadays is to find a more theoretical way of studying networks. The most influential approach in this kind of work is Social Network Analysis (SNA). Researchers of the ancient world, like Irad Malkin, Carl Knappett and Kostas Vlassopoulos, all, in one way or another, introduce Social Network Analysis into our field of research. It has been a methodological tool developed and used by social scientists since the 1960s, starting with Stanley Milgram and his studies about the "Six Degrees Paths". We can also highlight Mark Granovetter and his work on the strength of weak ties (1983), and more recently the mathematical evidence of the Small World Theory by Strogatz and Watts (1998).

"Social Network Analysis emphasizes the importance of relations between social entities, and examines the patterns and implications of these relations" (Malkin et al., 2009: 3). This sentence can be found in the preface (Networks in the Ancient Mediterranean) for the $22^{\text {nd }}$ volume of the Mediterranean Historical Review, which is dedicated exclusively to studies dealing with Social Network Analysis and a myriad of ancient world topics. The compilation, published almost ten years ago, was edited by Irad Malkin, Christy Constantakopoulou and Katerina Panagopoulou, and later published as a book Greek and Roman Networks in the Mediterranean. It is a compilation of research in ancient history that used, in one way or another, the idea of a network. The editors, in addition to encouraging this kind of work, also wrote that we, classicists, need to go beyond descriptive networks, that is to say, they suggest that we need "to qualify networks, to understand their duration, function, scope, overlapping, and historical implications" (Malkin et al., 2009: 2).

We could say that, in the terms put forward by Thomas Kuhn (2010), we have been experiencing a paradigm shift in ancient world studies. The works about the Mediterranean written by Fernand Braudel and by Peregrine Horden and Nicholas Purcell influenced a generation of researchers and set the ground for 
the emergence of Network Studies in Ancient History. Malkin asserts that:

It is driven from the need to understand both 'Mediterranean' and social structures, to analyze the factors that determined their shape and the flow of communication within them, and ultimately to understand the motors that led to transitions towards new structures (Malkin et al., 2009: 6).

Carl Knappett - who is more concerned with the influence of network theory on archaeological studies - warns us about the problem of the lack of "agency" in this kind of approach, thus it is the structures rather than the agents that tend to be emphasized when we use Social Network Theory. It happens when variations of the network are not considered. Variants like the growth and dynamics of the networks need to be taken into consideration. In other words, time, space and exchange are very important in these kinds of approaches. Knappett proposes a theory that explains interactions and changes instead of just describing them. His solution to these problems is to emphasize the causes of the transformations on the networks. Therefore, he can find these causes in the interactions between human and non-human protagonists in socio-material networks in the Archaic Period (Knappett, 2013: 8-13).

I would like to present briefly two other specific pieces of research that use network thinking and that shall be useful in this article. First, there is Irad Malkin's Small Greek World. It is a fascinating attempt to analyze the formation of "Greek Civilization" before the Classical Period in terms of the formation of the Mediterranean Network of cities. He describes it as follows:

The eighth century started the process of transforming disparate maritime cultures into a Mediterranean civilization based on ties among mostly city-oriented nodes. Phoenicians, Greeks, and to some degree Etruscans were founding new settlements, thus signaling a social and political model 
diametrically opposed to what the far more affluent ancient Near East had to offer (Malkin, 2011: 22).

What is interesting in Malkin's approach is not just his definition of a historical network that can be easily extended to our analysis. His analytical proposal is useful as well. First of all, a historical network needs to be identified; then, the characteristics of the network must be understood; thirdly, it is essential "to locate those problems that are better served by a network approach"; and the last thing to do is to examine the implications of the network approach for the studied object (Malkin, 2011:25).

He sees as an advantage of the network approach the fact that he can go through a very deeply studied subject, such as archaic Greek identity, and look for things that others might have missed. He says that "network perspectives reveal much more about ancient mental maps of space and connectivity than modern atlases and historical maps of ancient Greece" (Malkin, 2011: 19). So, in this way, he is able to analyze the colonial experience of the Greek polis, understand the cognitive maps of these people and realize that it is the distance that brings them all together. Or, as he puts it:

I believe that colonization informed and strengthened the nascent idea of Greekness primarily because the initial colonial experience was similar and common, and its initial problems and solutions were quickly copied among colonies that had different origins and were at great distances from each another (Malkin, 2011: 63).

Malkin identifies some syncretism between the Greeks' and the Phoenicians' colonial experiences, such as they both developed in a Mediterranean network where ports and shores relate to each other in a maritime network of connections that was present from the eighth century $\mathrm{BC}$ on and prominent in the sixth $\mathrm{BC}$; both people developed a political culture of city-states; they experienced similar enterprises of founding new city-states in overseas lands and they had in common a malleable and interchangeable context of polytheistic religion. So, he argues that any work that 
intends to analyze the Mediterranean Network of the first millennium needs to take this syncretism into consideration.

Just like Irad Malkin, Michael Sommer proposes a network way of thinking about the Phoenicians' colonial experiences. In the article entitled Networks of commerce and knowledge in the iron age: the case of the Phoenicians (2009) he states that this 'network' paradigm is most apt for explaining the genesis of the Phoenician commercial diaspora in the Mediterranean and its gradual transformation into an informal empire dominated by Carthage (Sommer, 2009: 102). He points out the existence of an open Mediterranean network that, because of its dynamism, led to the rise of the prominence of Carthage over part of the Western Mediterranean. Sommer argues that we need to look through this network and its dynamics, namely : how do information, people and material flow in this network and how do the existing ties create new ones? His conclusion is that by the middle of the fifth century $\mathrm{BC}$, there was a complete reorganisation of the Mediterranean system, "from which the west largely benefited - not only Carthage, but in the long run also Rome" (Sommer, 2009: 101).

\section{3. \\ The Matter of Scale}

So, how can this approach be helpful to answer the questions stated at the beginning of this article? Using Network Theory, how can we rethink some sources such as Strabo, who clearly considers other transformation forces aside from Rome?

The first valuable tool is the possibility to work with different scales. "Network approaches facilitate the articulation of different scales of interaction" (Knappett, 2013: 10), says Carl Knappett. It means that we could, in the first moment, try to fragment that information into different levels of analysis, or into different networks, and then articulate them all in a narrative about the relationship between these parts. 
If we start from the region where Strabo locates Gades, it belongs to Turdetania. He first describes its coast, an area with a vast number of cities inhabited by Phoenicians (Strabo 3.2.13). Gades is for Strabo the most relevant of them (Strabo 3.2.1). The distribution of goods produced in the interior of Turdetania, including its own products, especially salted-fish, is made on the coast. Then, he presents the countryside with the most important city of Corduba, in which the rivers are essential for the transportation of agricultural and mineral goods produced there.

Strabo describes a mental map of a local network that must be analyzed in its own terms. For example, the cities are the nodes, the links between which we need to find. They could be cultural, at least for those that share the Phoenician heritage; they could be economic, with the Guadalquivir river playing a very important role as a facilitator of connections between the two zones. In addition, Gades, Corduba and other cities, like Hispalis, could be seen as clusters in this network, because more connections were concentrated there than on other nodes, for example, a direct connection with Rome.

At this point of the analysis, the scale is a very important aspect to deal with. Rome is, in fact, a very important node that connects this network with a wider one, but there are also some other links to be identified. Strabo tells us about the ships that are produced there and sail on both the Mediterranean and the Atlantic; there are descriptions of migration from the North Africa to Turdetania and of notorious people that came to Gades to visit the Melqart/Heracles Sanctuary. Gades and the Turdetanian region are part of a Mediterranean network that, at least in Strabo's times, has Rome as a very important actor, but which is bigger and more complex than that. The network approach gives us the opportunity to bind all these different kinds of information into a complex network ready to be understood.

We can agree that this view is too "Strabonian". However, we should consider that Strabo relies in his description on many other writers, "official information" and oral traditions; that is, we should assume that all this knowledge is part of an informational network that can be traced and historicized. Strabo himself 
cites his main sources, like Polybius, Artemidorus, Posidonius, Eratosthenes, et cetera. The next step that needs to be taken is to understand how this mental map of a local network connected to a wider one changed until it formed the one presented by Strabo.

In conclusion, the purpose of this paper was to show the advantages of a research approach based on Network Theory. There is a well-known topos of historiography according to which Romans marched to Iberia to fight the Carthaginians, with some historians defending these actions, saying that they "freed” the Peninsula's population from the Barcids². This way of thinking leads us, on the one hand, to the idea that the Romans built a new society from the ground, or from scorched earth. Therefore, these narratives attribute foreign people with too important a role, and leave almost no space for others to act. On the other hand, we cannot deny the existence and the power of the Romans. In the approach I tried to present, this kind of dichotomy does not exist. If my assumptions are not completely wrong, it is very plausible to say that much of what can be identified as Roman domination is actually built on Phoenician, Greek and Carthaginian networks, at least in the southern part of the Iberian Peninsula. That is, the relationship between Gades and the Mediterranean network changed over time, and a close look at the links between the city and its surroundings can help us understand the dynamics of an ancient global process of integration.

\section{Bibliographie}

Aubet, M. E. (1993): The Phoenicians and the West: politics, lemons, colonies and trade. Cambridge: Cambridge University Press.

Blake, E. (2013): "Social Networks, Path Dependence, and the Rise of Ethnic Groups in pre-Roman Italy". In: C. Knappett, Network Analysis in Archaeology: new approaches to regional interaction. Oxford: Oxford University Press, 203-221.

Blázquez, J. M. (1978): Historia de España Antígua. Madrid: Ediciones Cátedra.

2 One of the canons of this idea is Blázquez (1978). 
Coward, F. (2013): "Grounding the Net: Social Networks, Material Culture and Geography in the Epipalaeolithic and Early Neolithic of the Near East (21,000-6,000 cal BCE)". In: C. Knappett, Network Analysis in Archaeology: new approaches to regional interaction. Oxford: Oxford University Press, 247-280.

García Vargas, E. (2014): Comer a la moda: imitaciones de vajilla de mesa en Turdetania y la Bética Occidental durante la antigüedad (s. VI a. C. - VI d. C.). Vol. 46, Barcelona: Universitat de Barcelona, Publications i edicions.

García Vargas, E., Alvelda, E. F. (2001): "Las salazones de pescado de la Gadir Púnica: Estructuras de producción”, Laverna XII: 21-41.

García Vargas, E., García Fernández, F. J. (2009): “Romanización y consumo_ cambios y continuidades en los contextos cerámicos de Hispalis en épocas turdetana y romano-republicana". SPAL 18: 131-165.

García Vargas, E., García Fernández, F. J. (2012): "Los hornos alfareros de tradición fenicia en el valle del Guadalquivir y su perduración en época romana: aspectos tecnológicos y sociales". SPAL 21: 9-38.

García y Bellido, A. (1945): España y los españoles hace dos mil años según la geografía de Strabon, Buenos Aires: Esapsa-Calpe Argentina.

Guarinello, N. L. (2013): História Antiga. São Paulo: Contexto.

Horden, P., Purcell, N. (2000): The Corrupting Sea: a study of Mediterranean History. Oxford: Wiley-Blackwell.

Isaksen, L. (2013): “O What a Tangled Web We Weave - Towards a Practice That Does Not Deceive". In: C. Knappett, Network Analysis in Archaeology: new approaches to regional interaction. Oxford: Oxford University Press, 43-70.

Keay, S. (2003): "Recent Archaeological Work in Roman Iberia (1990-2002)". The Journal of Roman Studies 93: 146-211.

Knappett, C. (2013): “Introduction: Why Networks?”. In: C. Knappett, Network Analysis in Archaeology: new approaches to regional interaction. Oxford: Oxford University Press, 3-16.

Kuhn, Th. (2010): A estrutura das revoluções científicas. 10 ed. Trad. B. Boeira. São Paulo: Perspectiva.

Malkin, I. (2011): A small Greek world: networks in the Ancient Mediterranean. Oxford: Oxford University Press.

Malkin, I., Constantakopoulou, C., Panagopoulou, K. (2009): Greek and Roman networks in the Mediterranean. Londres: Routledge. 
Megias, V. (2014): “Formas que cambian, engobes que permanecen. Una visión diacrónica de las imitaciones de vajilla de tipo Kuass en el Valle del Guadalquivir”. In: F. J. García Fernández, E. García Vargas, Comer a la moda: imitaciones de vajilla de mesa en Turdetania y la Bética Occidental durante la antigüedad (s. VI a. C. - VI d. C.), Vol. 46. Barcelona: Universitat de Barcelona, 175-204.

Morris, I. (2005): “Mediterraneanization”. In: I. Malkin, Meriterranean Paradigms and Classical Antiquity. New York: Routledge, 30-55.

Pellicer Catalán, M. (1982): "Las cerámicas del mundo fenicio en el bajo Guadalquivir. Evolución y cronología según el Cerro Macareno (Sevilla)". In: H. G. Niemeyer, Phönizier im Westen. Die Beiträge des Internationalen Symposiums über "Die Phönizische Expansion im Westlichen Mittelmeerraum", Köln, Vom 24. Mainz am Rhein: Zabern, 201-219.

Principal, J., Ribera i Lacomba, A. (2013): “El material más apreciado por los arqueólogos la cerámica fina la cerámica de barniz negro”. In: A. Ribera i Lacomba, Manual de cerámica romana: del mundo Helenístico al Imperio Romano. Alcalá de Henares: Museo Arqueológico Regional, 43-146.

Rivers, R., Knappett, C., Evans T. (2013): “What Makes a Site Important? Centrality, Gateways, and Gravity”. In: C. Knappett, Network Analysis in Archaeology: new approaches to regional interaction. Oxford: Oxford University Press, 125-150.

Rouillard, P. (1985): “Les céramiques grecques archaïques et classiques en Andalousie: acquis et aproches”. In: M. Picazo, E. Sanmartí, Ceràmiques gregues i helenístiques a la Península Ibèrica. Barcelona: Diputació de Barcelona/ Institut de Prehistòria y Arqueologia, 73-92.

Sáez Romero, A. (2014a): “Imitaciones en las vajillas de mesa en la Bahía de Cádiz desde la transición tardoarcaica hasta la época tardopúnica. Actualización de los datos y nuevas propuestas”. In: F. J. García Fernández, E. García Vargas, Comer a la moda: imitaciones de vajilla de mesa en Turdetania y la Bética Occidental durante la antigüedad (s. VI a. C. - VI d. C.), Vol. 46. Barcelona: Universitat de Barcelona, 33-78.

Sáez Romero, A. (2014b): “Oculto bajo el barniz. Aproximación inicial a las producciones grises de Gadir de época tardoclásica-helenística - siglos IV/III a. C.". In: F. J. García Fernández, E. García Vargas, Comer a la moda: imitaciones de vajilla de mesa en Turdetania y la Bética Occidental durante la antigüedad (s. VI a. C. - VI d. C.), Vol. 46. Barcelona: Universitat de Barcelona, 79-118. 
Salmonte, F. J. L. (2011): Nueva História de Cádiz. Madrid: Sílex Ediciones.

Schulten, A., Gimpera, P. B. (1956): Fontes Hispaniae Antiquae, II-VI. Barcelona: Universidad de Barcelona.

Shefton, B. J. (1982): "Greeks and Greek Imports in the south of the Iberian Península. The archaeological evidence”. In: H. G. Niemeyer, Phönizier im Westen. Die Beiträge des Internationalen Symposiums über "Die Phönizische Expansion Im Westlichen Mittelmeerraum" in Köln Vom 24. Mainz am Rhein: Zabern, 337-368.

Silva, B. S. (2013): Estrabão e as Províncias da Gália e da Ibéria: um estudo sobre A Geografia e o Império Romano. São Paulo: Universidade de São Paulo.

Terrell, J. E. (2013): "Social Network Analysis and the Practice of History". In: C. Knappett, Network Analysis in Archaeology: new approaches to regional interaction. Oxford: Oxford University Press, 17-42.

Villedary y Mariñas, A. M. N. (2014): "El éxito de la vajilla helenística 'tipo Kuass' ¿Resultado de la adopción de una moda Estética o reflejo de transformaciones culinarias y comensales?". In: F. J. García Fernández, E. García Vargas, Comer a la moda: imitaciones de vajilla de mesa en Turdetania y la Bética Occidental durante la antigüedad (s. VI a C. - VI d. C.), Vol. 46. Barcelona: Universitat de Barcelona, 119-174. 